\title{
OPTIMALISATION THE USE OF HOUSEHOLD-SCALE WATER PUMP MACHINES WITH THE ARDUINO NANO v3.0 CONTROL SYSTEM
}

\author{
Idkhan A.M., Triyono M.B., Iskandar S., Anwar B.* \\ University of Negeri Makassar \& University of Negeri Yogjakarta, Indonesia \\ *E-mail: soet 54mks@yahoo.com
}

\begin{abstract}
The need of clean water keep increasing, therefore some energy sources that are classified in the renewed energies such as solar energy, wind energy, etc. This research is conducted to analyse usage of water pump engine by using the automatic switches of controller arduino nano v.3.0 and solar energy as the homebased scale pump actuator. The experimental research against the automatic switches usage and solar energy with battery photovoltaic ( $P$ V) for water pump actuator electric energy generator is done in the Renewable Energy Laboratory at Mechanical Engineering Department of State university of Makassar. The result of research shows the sun intensity excelsior, hence battery generator output power PV obtained excelsior to also. Maximum current of PV is obtained at 13.35 Central Indonesia Time Zone (local time) 599 Watts. Current or generator output power PV obtained hardly having an effect on to performa pump and water debit yielded. Water debit yielded by pump at 08.00 until Pukul 16.00 is 0,8 Liter/minute. The controller system with this PV generator is able to deliver water to reservoir with head 3.5 meter.
\end{abstract}

\section{KEY WORDS}

Control, water pumps, photovoltaic cells, energy sources.

The clean water is one of a real important energy source in human life, where a lot of clean water applied for various human activities so that the activity to take care of clean water availability needs to be done and guarantee human life proceeding every day. To guarantee the availability of clean water we need to do the thrift effort and its usage way so that the renewed energy will be more economic that move the water pump. The usage of various technologies to guarantee the water pump performance so the technology application to produce the energy endurance is renewed by using the water pump actuator.

By guarantying the availibility of electric energy through usage of battery photovoltaic and when its operation, it is determinable based on availibility of electric energy at battery, so we must apply the microcontroller technology and usage of various censor types which can arrange all commands and source which will be processed to become an output to guarantee the functioning of a water pump.

\section{LITERATURE REVIEW}

Energy is human basic need, keep increasing in line with the level of life. Oil fuel/fossil energy is one of energy source that has character of non renewable energy sources which during the time is pledge in order to fulfill requirement of energy of diatomic in various activity sectors. Besides that, the energy resources in Indonesia covers water power (hydropower), geothermy, ground gas, embers stone, turf, biomass, biogas, wind, sea energy, sun, etc, can be used as the alternative energy.

Sun panel or solar cell is device to convert solar energy into electric energy, technology photovoltaic works to change or convert the radiation of the sun and becomes electric energy in, photovoltaic usually a unit which able to be named module, in a photovoltaic consisted of many solar cell which are able to be compiled in form of break evenly and also parallel. Beside solar energy is a semi element of conductor which solar energy conversion can become electric energy on the basis of effect photovoltaic. 


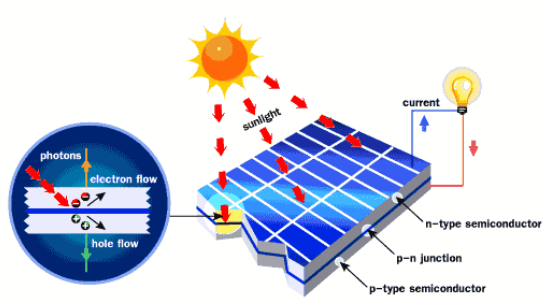

Figure 1 - Scheme photovoltaic

Control systems is processing which consist of a group of apparatus and equipments equipments of electronic capable to handle stability, accuration, and elimination of transition of dangerous status in the production process. Each control system component plays an important role, for example, if there is no censor or destroyed or doesn't work, hence process control systems will not know what is going on in running process (Ogata, 1995).

Pump is one of engine type that functions to remove fluid substance from a place to the purposed place. The fluid substance such as water, oil or lubricating oil, and other fluid substance of which is not compressed. Pump which is used by many industries use the aid equipment that is important for production process. For example at steam power electric revival, pump is used to supply the feed water to the boiler or assists the water circulation which will be evaporated in boiler.

The greatness of energy or power that is required to turn around the pump axis influences by pump capacities, pump total head, fluid specific gravity pumped, and the pump total efficiency.

This device design uses control systems and bases on arduino nano $v 3.0$ that is expected to make easier in controlling the water pump when it started to work till it stop. Arduino is not just a development toolkit, but it is combination trap of hardware, programming language and sophisticated integrated development environment (IDEA) IDEA is a software a real stands to write program, compiles to become binary code and upload into memory microcontroller.

Censor is the equipment that is used to change from a magnitude physical into electrical magnitude so that analyzable with certain electrical circuit. Almost all equipments of the electronic has censor in it. Nowadays, the censor has been made with very small size to facilitate its usage and economizes energy.

Most of censors that used nowadays can really communicate with the electronic peripheral which will do the measurement and recording. Censor is part of a real common for us in daily life. (Rafiuddin syam, 2013)

Battery as source of concurrent electric current (DC) can be grouped to become two kinds, that are dry element battery and wet element. Battery can be called as also with term of accu or accumulator that means muster. Battery is a tool which can yield electrical energy through chemistry process.

Battery has 2 electrodes that are: positive electrode and negative electrode. A payload Of incircuit with battery electrodes, the chemical electro will arise and happened current flow electric from positive pole towards negative pole. (Teknika, Vol 4: 2012).

LCD is one of electronic components that functions as appearance facility of a data, included character, letter, or graph. LCD requires the small strain and power so that it is often used for application at calculator, digital watch, and instrument of electronic such as digital multimeter.

Silicon and gallium are in the form of liquid crystal as light transsitter. At LCD, every matrix is arrangement of two pixel dimensions which are divided into battery and column. Thus every meeting of battery and column consisted of LED at background area (backplane) which is backside of glass ingot with inside part is closed over by the transparence electrode layer. Under normal circumstances, the used fluid has bright colour.

Then the colour of certain districts at the fluid will turn into black when strain is applied between flat areas and electrode cupola is found on the side in front part glass. Excellence 
uses LCD is consumption of energy that is small relative and draws small current (some ampere microes), so that device or system becomes portable because it can apply small energy allowance. Other excellence is LCD size that is fix namely not undersize and not too 15 big, then appearance showed from legible LCD easily and clearly (Setiawan, "Mikrokontroler ATMEGA 8535 Bascom-AVR", 2010: 24-27).

\section{RESULTS AND DISCUSSION}

The data specification of measurable phototvotaic at Standard Testing Condition (STC) with radiation intensity of the sun reachs $1000 \mathrm{~W} / \mathrm{m}^{2}$ and solar panel temperature $25^{\circ} \mathrm{C}$ are as follows:

- Model: XHGD-50W;

- Open circuit voltage $\left(\mathrm{V}_{\mathrm{oc}}\right): 21,36 \mathrm{~V}$;

- Short circuit current $\left(\mathrm{I}_{\mathrm{sc}}\right): 3,13 \mathrm{As}$;

- Maximum power voltage $\left(\mathrm{V}_{\text {maks }}\right): 17,8 \mathrm{~V}$;

- Working temperature: -45 to $+85^{\circ} \mathrm{C}$;

- Tolerance: $\div 3 \%$;

- Maximum power $(\mathrm{Pm}): 50 \mathrm{~W}$;

- Length solar cell: $67 \mathrm{~cm}=0,67 \mathrm{~m}$;

- Width solar cell: $58 \mathrm{~cm}=0,58 \mathrm{~m}$;

- Solar cell surface area: $0,38 \mathrm{~m}^{2}$.

Data obtained from assaying will be calculated and analysed to get photovoltaic efficiency. During research, the data taken started at $08.00-16.00$ Wita.

Result data observation cell photovoltaic at Saturday, 9 November 201712.05 WITA that as calculation example as the next:

- Water debit $(\mathrm{Q})=111 \mathrm{~L} / \mathrm{menit}$;

- Wide cell photovoltaic $(A)=0,38 \mathrm{~m}^{2}$;

- Radiation intensity of the sun $(E)=1265.2 \mathrm{~W} / \mathrm{m}^{2}$;

- Brief connection current $\left(\mathrm{I}_{\mathrm{sc}}\right)=4.5 \mathrm{~A}$;

- Opened connection strain $\left(\mathrm{V}_{\text {oc }}\right)=20 \mathrm{~V}$;

- Current $\left(\mathrm{I}_{\mathrm{m}}\right)=5.0 \mathrm{~A}$;

- Strain $\left(\mathrm{V}_{\mathrm{m}}\right)=12 \mathrm{~V}$;

- Water specific mass $(\rho)=993,898 \mathrm{~kg} / \mathrm{m}^{3}$;

- Water spesific heat $\left(\mathrm{C}_{\mathrm{p}}\right)=4,178 \mathrm{~kJ} / \mathrm{kg}^{\circ} \mathrm{C}$.

After taking the data and analyzing the data and result of calculation at research, the sun intensity influence to pump efficiency which can be converted to become electric energy at housing pump, can be seen. These things are explained more detail at some graphs the relation of following:

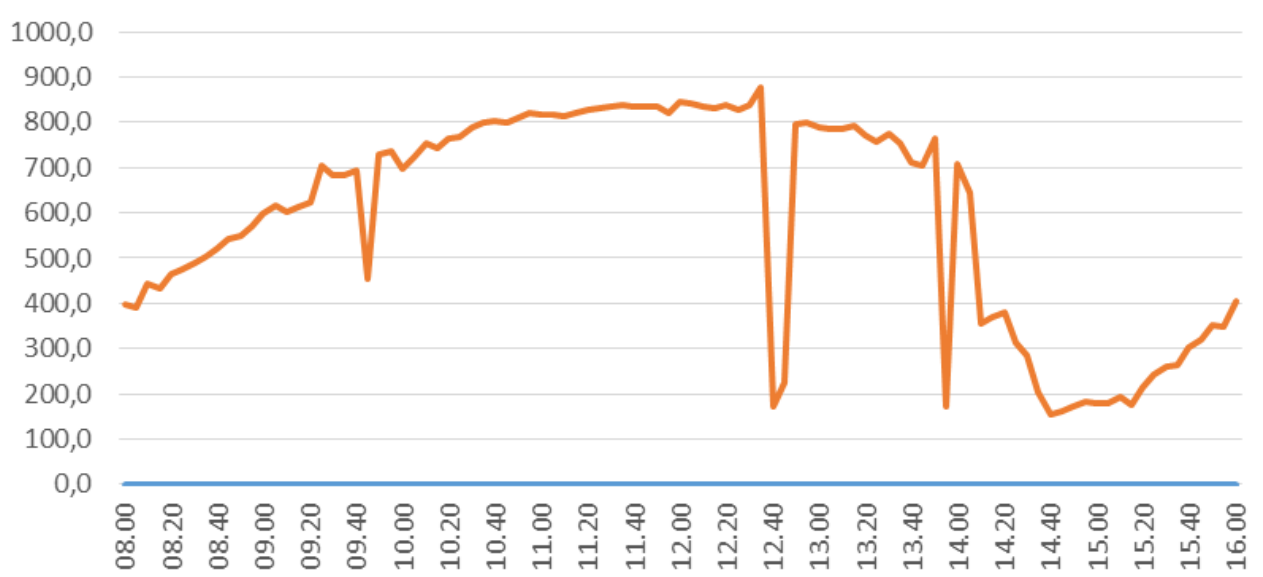

Figure 1 - Graph the relation of the sun intensity (E) to time (t), Day 1 
The relation of the sun intensity $(E)$ and time (t) can be seen at above graph. The graph of the First day, Thursday 9 November, and Tuesday, 14 November 2017 shows the sun Intensity from 08.00 o'clock to 11.20 keep Increasing:

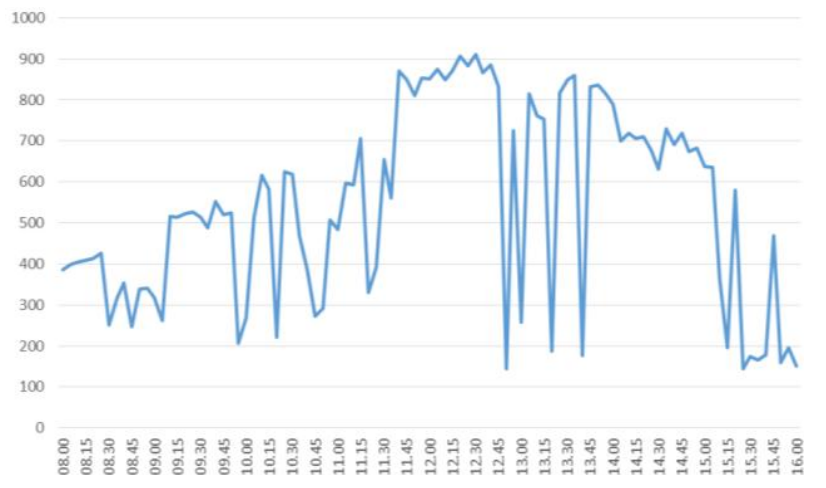

Figure 2 - Graph the relation of the sun intensity (E) to time (t), Day 2

But it is noted at 12.45 the intensity suddenly declines because of overcast wheater condition. There are 2 days of data taking and it is noted the highest intensity on Thursday and Tuesday, 14 Novembers 2017 at 12.30 that is $898,5 \mathrm{~W} / \mathrm{m} 2$. From inferential graph can be concluded that increasing of highest the sun intensity at 12.35 until 12.40 , so it can be concluded that that weather state influence the reducing and increasing of the sun intensity that read based on the measurement instrument.

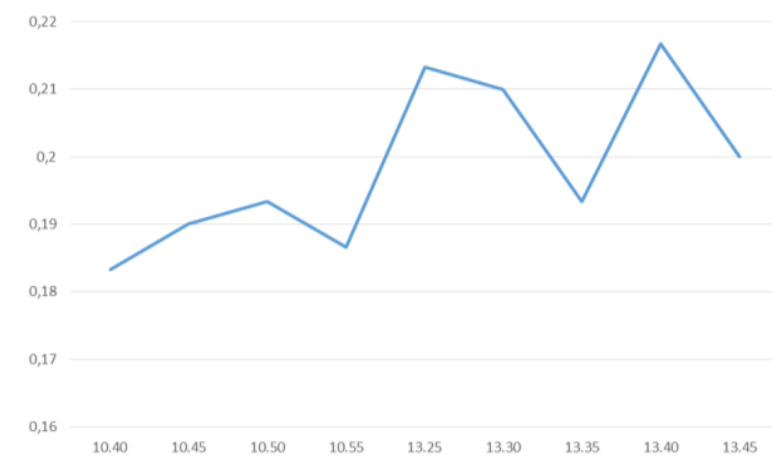

Figure 3 - Graph the relation of water power to time (t)

On Thursday, 9 November 2017 water power from 10.55 to 13.25 increased, but it is noted at 13.45 water power reduced because of the overcast weather condition in 2 days of data taking is noted by highest water power noted on Thursday, 9 November 2017 at 13.40 increased. It can be concluded that increasing of the highest water power at 13.25 until at 13.40. The weather Condition and the sun temperature influence the reducing and the increasing of water power.

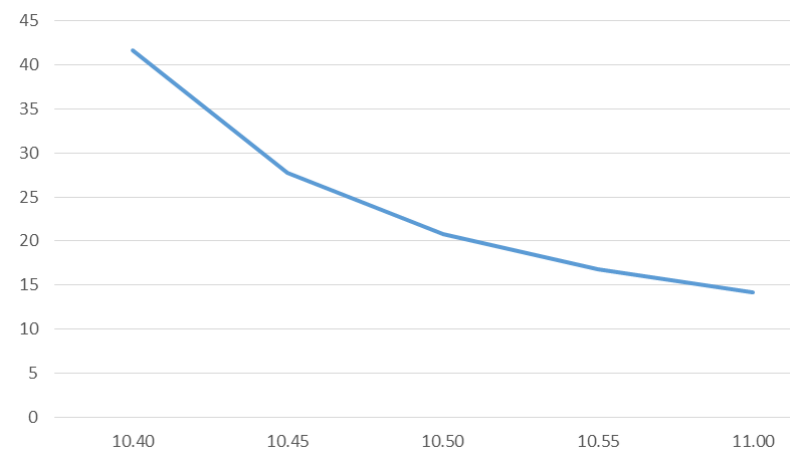

Figure 4 - Graph the relation of device efficiency to time 
In executing this research there are 3 principal components that function as the electric revival ternator, that is photovoltaic and Pump as water distributor from reservoir 1 to reservoir 2 and controller device automatically of third pump of principal components inil which will make a system pumping of clean water which the generator from $p-v$ with energy source comes from the sun

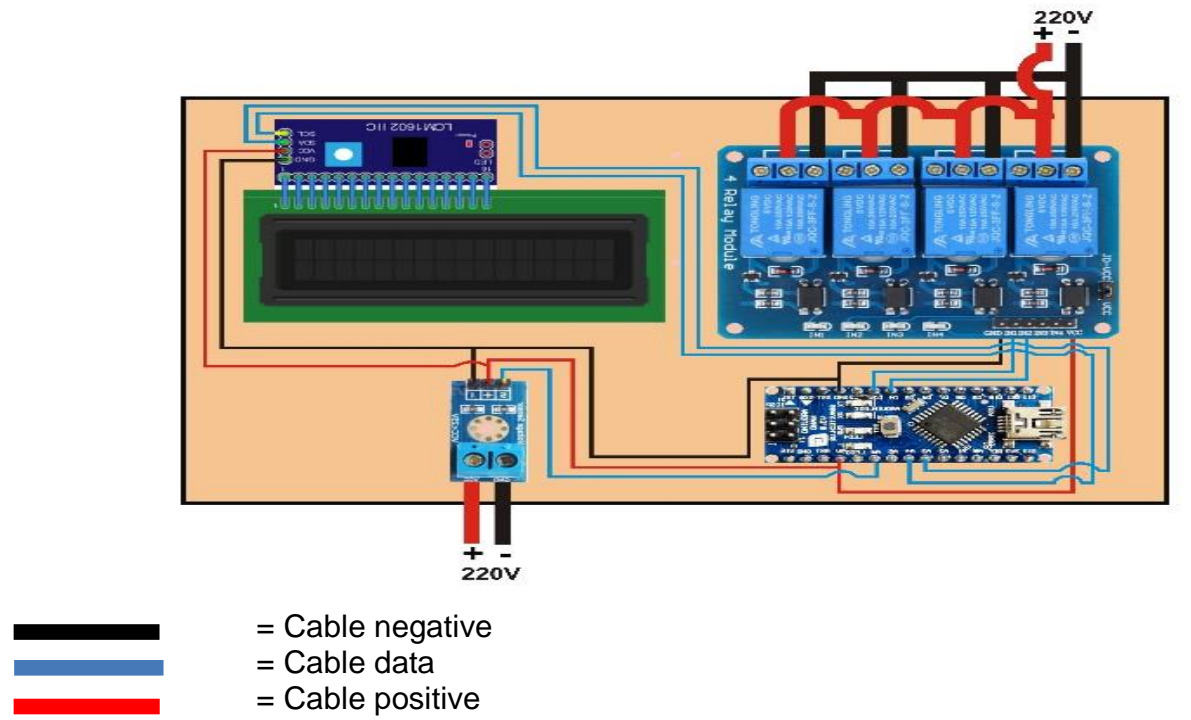

Figure 5 - Design controller device

Known that the sun intensity hardly having an effect and base on direction angle to come it the sun, maximum power there is at angle of $90^{\circ}$ (vertical with wide of panel), but every region has angle of latitude different, for region Makassar photovotaic is attached with angle of dip ( $\beta) 15^{\circ}$ to get angle of latitude $90^{\circ}$.

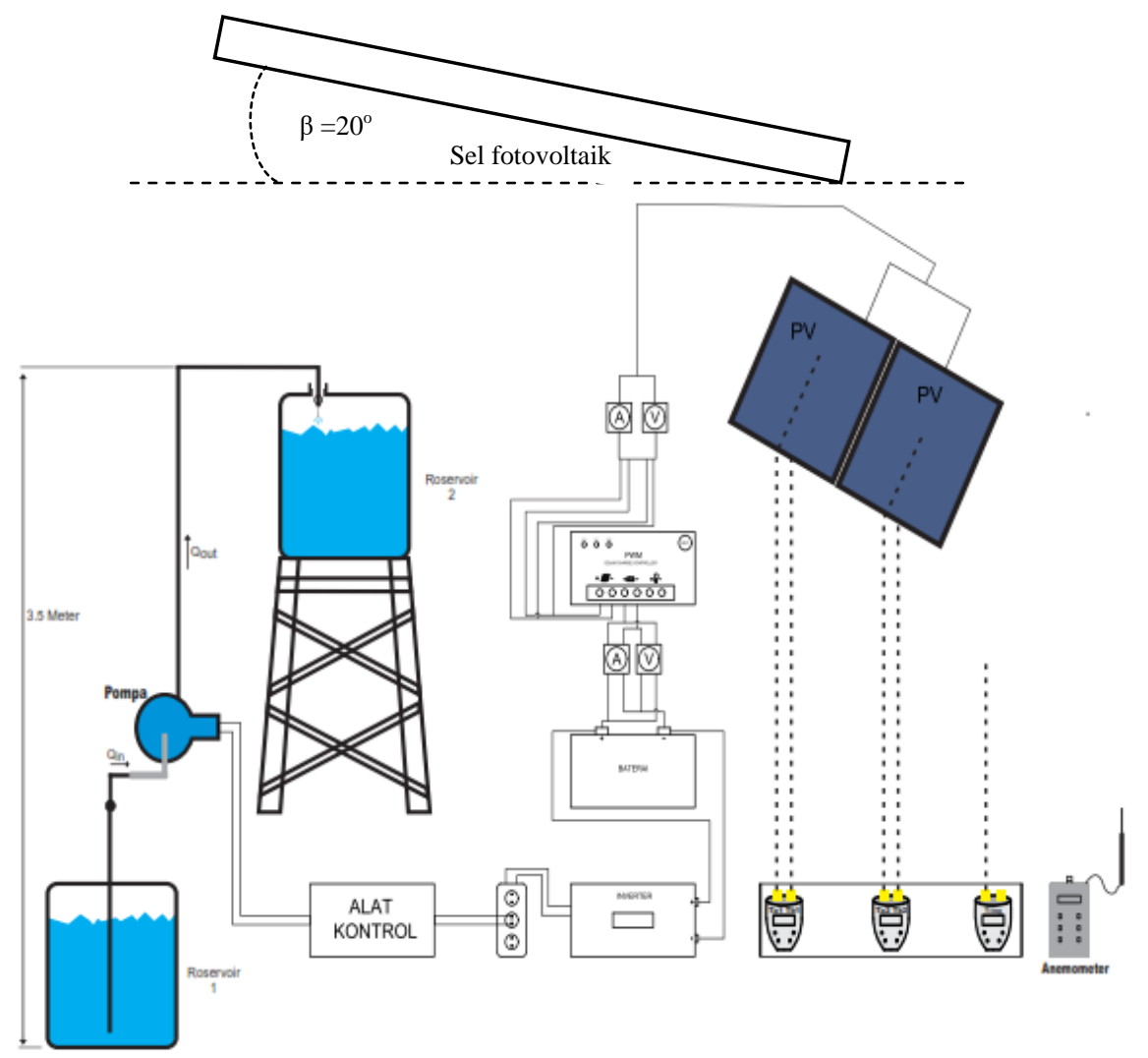

Figure 6 - Scheme prototype and point of measuring 


\section{CONCLUSION}

The electric revival used is the type of solar panel 50 WP polycristal with the width of $0,38 \mathrm{~m}^{2}$ has 2 panels and the pump is modified with revolution $4800 \mathrm{rpm}$ with its motor efficiency equal to $80 \%$ and is attached with angle of dip ( $\beta$ ) $20^{\circ}$ in order to get angle of latitude $90^{\circ}$ and flows water from floor 1 to floor 2 as high as 3.5 meter.

From the calculation analysis resykr can be seen that output power from photovoltaic hardly influences pump performance. With usage of the controlling device when pump works, it can be regular according to the available level battery. The result of testing of device and analysis and graph reading indicated that usage of pump can be be regular by using the controlling that there are in this device.

It is better for the next testing, the research to be done with dip of different photovoltaic that we can know the maximum absorpsion energy.

\section{REFERENCES}

1. Bastomi, Akhwan., 2010, Simulation of Conversion Energy Wind Becomes Dissociation energy of diatomic Electricity At Axis Wind Turbine Horizontal. Worse luck: Country Islam University.

2. Maulana Malik Ibrahim. Ikhwanul Ikhsan. 2011. Encumbering Influence Analysis to Wind mill Performance Tipe Propeller Pada Wind Tunnel Sederhana. http://repository.unhas.ac.id/

3. Kadir, Abdul. 1995. Nature Energy Source. Jakarta: Penerbit Universita Indonesia (UIPress)

4. Nursuhud, Djati dan Astu Pudjanarsa., 2008. Energy Conversion Engine. Yogyakarta: Penerbit Andi.

5. Soetyono Iskandar. 2017. Energy Conversion. Yogjakarta: Deepublish.

6. Soetyono Iskandar. 2018. Electrical System of Solar Energy. Yogjakarta: Deepublish.

7. Suryatmo, F. 2014. Electrical Engineering Basics. Jakarta: Rineka Cipta.

8. Tanto, Joni. 2010. Influence Various Regulator Aperture to Characteristic.

9. Wibowo, FAB. 2003. Analysis Performamce Efisiensi Auxiliary Oil Pump (Lube Oil Pump) WOT (Kelompok Kerja Teknik Pembangunan University Of Twente). 2015. Rope Pump A Wooden Model For Hand Dug Wells And Boreholes. University of Twente. 